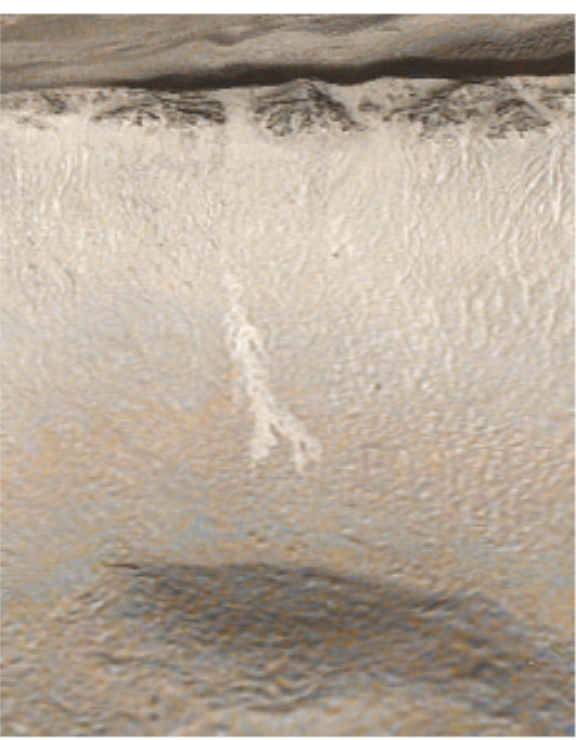

The appearance of light-coloured gullies on Mars suggests water has flowed there in recent years.

aquifers, Christensen says any underground water would have leaked out and evaporated millions of years ago.

That's a puzzle that Malin has yet to solve. He has several arguments for why some of the water below the surface might be liquid: salts might have lowered its melting point, or the subsurface of Mars may be warmer than previously thought. But it's unclear where the water is coming from. Malin speculates that it comes from melting surface ice or that it has existed in the planet's deep interior since Mars formed.

Christensen favours a model in which packets of surface snow melt when the climate warms. Other experts are divided. McEwen suspects both Christensen and Malin are right, whereas Vago is not so sure whether Mars has the right conditions to keep underground water liquid.

Either way, the finding that groundwater is seeping out of Mars is hugely significant for those who hope one day to find life on the planet. Liquid water is essential for life - at least for anything like life on Earth. And iflife does exist on Mars, the only place it is likely to be able to survive is underground, and that is out of reach of our probes. If liquid water from aquifers is making it to the surface, it might carry microorganisms with it - although once there, they are unlikely to survive more than a few seconds. "It means that in the search for life, water is accessible and at the surface," says McEwen.

Malin points out that, so far, there is no evidence of biological activity on Mars. But he adds: "Our results certainly point to a place where biological activity might occur." Katharine Sanderson

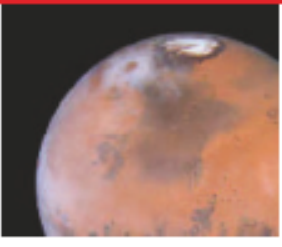

MARS INFOCUS

Find all our stories on the red planet in one place. www.nature.com/news/ infocus/mars.html

\title{
A vision of life after Blair
}

Tony Blair's choice of successor as Britain's prime minister has seemed little more than a formality since he announced in September that he would stand down. So UK scientists have begun to wonder what a government led by Gordon Brown, the current chancellor of the exchequer, would be like.

A few hints emerged last week, when Brown unveiled his annual pre-budget report. UK researchers have rarely questioned Brown's commitment to research, given that he has boosted science spending by $70 \%$ to $£ 2.5$ billion (US $\$ 4.9$ billion) since 1997. But his largesse comes with a desire to micro-manage and a dose eye on what industry wants. So it is little surprise that Brown's report reinforces his commitment to science, while raising fears about how he might govern it.

For example, the report restated an intention, first aired in March, to ensure that the Department of Health's research funds actually get spent on research. At present, a sizeable fraction of the department's $£ 600$-million research budget gets diverted to the National Health Service.

But Brown's blueprint for this reform looks complex and perhaps slanted in industry's favour. Funds for the Medical Research Council and the health department would be coordinated by a new body, the Office for Strategic Coordination of Health Research. Another new organization, the Translational Medicine Funding Board, would work with these to get results from bench to bedside, raising the possibility that basic-research funds could be raided to pay for work that industry wants done.

Reforms to another mainstay of UK science have also received a mixed response. Every seven or so years, UK researchers undergo the Research Assessment Exercise (RAE), an expert review of university research used to distribute more than $£ 1$ billion of government money to higher-education institutes. Pleas for reform of this timeconsuming activity have grown louder in recent years, prompting Brown to launch a consultation on a metrics-based alternative earlier this year. With the results now announced, some critics may be wishing they had stayed silent.

Measures of external research income, postgraduate training and research impact, the last by citation analysis, are broadly in line with what researchers wanted. The plan also fits the treasury's desire to streamline the process. But the proposals would almost completely eliminate peer review. Bibliometrics experts say properly weighted citation statistics produce the same results as expert review, but many, induding the Royal Society, do not agree.

Ole Petersen, a cell biologist at the University of Liverpool who chaired the society's RAE panel, uses the story of Nobel prizewinner Bert Sakmann to explain why. Sakmann's key paper on ion channels was published in 1976, but citations didn't take off until new experimental tools came into use a decade later. If metrics had been used to evaluate Sakmann's paper in the mid-1970s, they would have returned a low score. "But everyone knew this was a breakthrough," says Petersen.

Even Brown's oft-repeated statement that science and the innovation that springs fromit should be central to Britain's economy could prove controversial. Some suggest he may create a Ministry for Science to push the idea. But this could mean shifting more funds from basic to applied research, as Brown did with $€ 60$ million of university money last week.

Brown's spending increases have turned Britain's labs around, but some fear that the future may look less certain if applied research is seen as the raison dêtre of science. "You always have to be wary when people march down that road," says Peter Cotgreave, director of the Campaign for Science and Engineering, a London-based lobby group. "They can forget about the science base."

Jim Giles

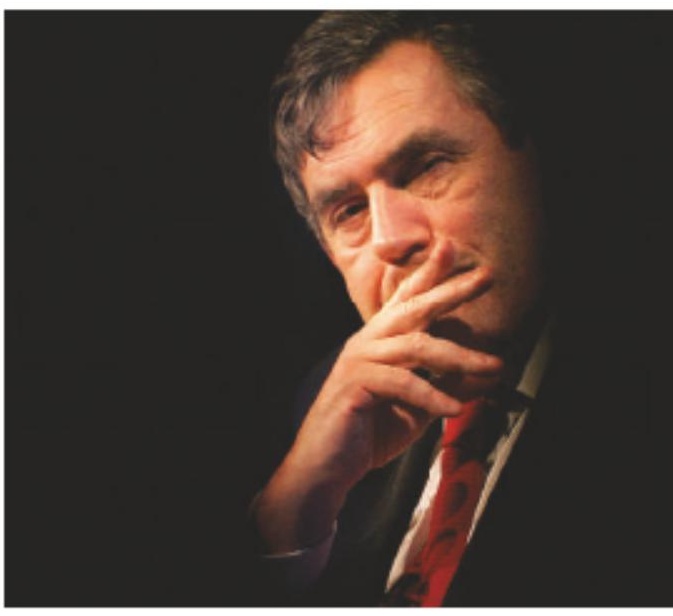

How will UKscience fare under Gordon Brown? 